\title{
ANKLAGEMYNDIGHEDENS ROLLE \\ - NOGLE KOMPARATIVE TANKER OM LEGALITET OG OPPORTUNITET I DET DANSKE OG DET TYSKE RETSSYSTEM
}

\author{
AF ADJunkt, DR. JUR. Birgit FELdTMAnN
}

The article investigates the role of the prosecution service in the German and the Danish systems of criminal justice. It raises the question of the importance and influences of the "opportunity principle" (also known as the "expedience principle") and/or the "legality principle" in both legal systems. The starting point of the investigation is the contradiction that while the two systems are generally understood to represent different categories, there are still significant similarities in the legal framework governing prosecutor discretion and its understanding: The German system is usually described as following the "legality principle", while the Danish system is seen as an example of the "opportunity principle". Nevertheless, a review of the two systems reveals that the prosecution service in both legal systems is in general obliged to prosecute if the evidence suggests that the prosecution will lead to a conviction. In both systems the prosecutor's alternatives for discretion provided by the law are seen as exceptions to this general rule.

The article investigates some important aspects of the use of discretion in the German and Danish legal systems and provides some explanations for the above mentioned contradiction. It reveals some similarities between both systems, but it also points out some important differences. One important factor that can be identified for the differences concerning the prosecutor's role and the use of discretion, are the differences between the legal culture of the two legal systems. The article concludes with some thoughts about the impact that such differences in legal culture could have on tendencies to extend cooperation in the field of criminal justice in Europe. *

"Når klokken er 11 i Danmark, er den 5 i U.S.A., 10 i London, og 18 i Kina og 13 omkring Moskva. Hvor er vi danske et udvalgt folk, at vi netop er født i selve det lille velsignede land, hvor klokken er 11, når den er 11."

Piet Hein beskriver i sit lille gruk enkelt, men rammende, hvordan mennesket tænker: Det, som vi er vant til, opfatter vi som det rigtige, mens det fremmede bliver opfattet som en mærkelig undtagelse. Denne tankegang findes også i * Title in English: The role of Prosecution: Comparative Perspectives on Legality and Opportunity
in the German and the Danish Legal Systems. Original in Danish. 
retsvidenskaben: Lov og ret og den videnskabelige behandling af begge er først og fremmest nationalt orienteret. Der findes ingen universel opfattelse af, hvad ret er, og behandlingen af retlige spørgsmål foregår traditionelt inden for det eksisterende nationale system.

Til trods herfor optræder talrige problemstillinger med retlige implikationer parallelt i forskellige retssystemer. For eksempel angår spørgsmålet om anklagemyndighedens rolle og kompetence i straffesager ikke kun det danske retssystem, men diskuteres i forskellige retssystemer.' Komparation af retssystemer er i den sammenhæng en nyttig metode, ikke blot med henblik på at stifte bekendtskab med fremmed ret, men også til at opnå bedre forståelse af eget retssystem.

Det grænseoverskridende perspektiv på straffe- eller procesretlige spørgsmål findes også af en anden grund i stigende grad oplagt: Det kan forventes, at det europæiske samarbejde på det strafferetlige område vil øges i fremtiden. EU's "tredje søjle" omfatter blandt andet et styrket samarbejde inden for strafferet. ${ }^{2}$ Med terrorangrebet mod USA i september 2001 har de kræfter, som ønsker en fælles strafferet eller i det mindste en fælles strafforfølgningspolitik inden for den Europæiske Union, fået ny medvind. I forbindelse med et intensiveret samarbejde eller endda en fælles strafferet tales også om etablering af en europæisk anklagemyndighed. ${ }^{3}$ Forudsætningen for enhver form for samarbejde på det strafferetlige område er indsigt i forskelle og ligheder i teori og praksis i de involverede landes strafferetssystemer.

For øjeblikket findes der ingen fælles opfattelse af eller koncept for anklagemyndighedens opgave og funktion i straffeprocessen i Europa. Der er retssystemer, hvis tradition for overhovedet at have en egentlig anklagemyndighed som fast element i straffeprocessen end ikke er særlig lang. ${ }^{4}$

Emnet for denne artikel er ét af de punkter, hvor retssystemerne ofte adskiller sig fra hinanden, nemlig spørgsmålet om, hvorvidt anklagemyndigheden uden undtagelse skal efterforske og rejse tiltale, hvis bevissituationen gør det sandsynligt, at den sigtede bliver dømt, eller om anklagemyndigheden har (eventuelt inden for visse grænser) en selvstændig skønsbeføjelse i dette spørgsmål.

Dette omtales i teorien som et valg imellem legalitetsprincippet og opportunitetsprincippet. Danmark antages som udgangspunkt at bekende sig til opportunitetsprincippet, mens Tyskland regnes som klassisk eksempel på et land med et rodfæstet legalitetsprincip. Men hvad betyder disse principper? Og hvori består de reelle forskelle mellem det danske og det tyske system?

\section{Legalitets- og opportunitetsprincip som kategorier for retssystemer}

Begreberne legalitets- og opportunitetsprincippet er ikke klart definerede. I Tyskland foregår der en indgående diskussion, med stærke modstående synspunkter, om, hvad forskellen mellem principperne egentlig er. Denne diskussion tager af gode grunde først og fremmest udgangspunkt i de tyske regler og den 
tyske anklagemyndigheds rolle i straffeprocessens praksis. ${ }^{5}$ I en komparativ analyse, som den der ønskes foretaget her, er denne vinkel imidlertid ikke tilstrækkelig. Her er det afgørende at finde frem til en definition, som kan bruges til kategorisering og sammenligning af forskellige retssystemer.

I Danmark er begreberne opportunitet og legalitet ikke så kontroversielle som i Tyskland. I Danmark går spørgsmålet simpelthen ud på at få afdækket, om, og $i$ hvor vid udstrækning, anklagemyndigheden har kompetence til at inddrage billigheds- og hensigtsmæssighedsovervejelser i sin afgørelse af, om tiltalen skal rejses. I Danmark er det endvidere antagelsen, at de fleste retssystemer i realiteten ikke kan kategoriseres som enten/eller, men ligger et sted imellem disse yderpunkter. ${ }^{6}$

I den tyske og den komparative litteratur bliver begreberne opportunitet og legalitet anvendt på to måder: For det første ses begreberne anvendt $\mathrm{i}$ "materiel forstand". ' Her er spørgsmålet, om enhver lovovertrædelse, stor eller lille, skal forfølges indtil domsafsigelsen, eller om forfølgelse kan undlades undervejs af forskellige retlige aktører. Denne forståelsesvariant ses ofte i tysk litteratur.

For det andet anvendes begreberne i "formel forstand". ${ }^{8}$ Spørgsmålet om legalitet eller opportunitet $i$ et retssystem er her begrænset til spørgsmålet om anklagemyndighedens kompetence: Forskellen mellem principperne består her $\mathrm{i}$, hvorvidt anklagemyndigheden har den formelle kompetence til at slutte en sag, hvor beviset antages at kunne bære til domfældelse.

Det er den anden forståelsesvariant, som sædvanligvis - og således også i denne artikel - fører til kategorisering af retssystemet som baseret på enten legalitets- eller opportunitetsprincippet. Legalitetsprincippet vil i sin rene form medføre, at anklagemyndigheden rejser tiltale i enhver sag med tilstrækkeligt bevis. Omvendt medfører et rendyrket opportunitetsprincip, at anklagemyndigheden har kompetence til at udøve frit skøn i spørgsmålet om tiltalerejsning eller ej. ${ }^{9}$ Det er i realiteten imellem disse yderpunkter, hvor de fleste retssystemer befinder sig. ${ }^{10}$

\section{Legalitet og opportunitet i de to retssystemer}

Det tyske strafferetssystem bygger, som sagt, på legalitetsprincippet. Denne kategorisering skyldes $\S 152$, stk. 2, og $§ 170$, stk. 1, i Strafprozessordnung $(S t P O)$. I § 152, stk. 2, pålægges anklagemyndigheden at indlede efterforskning, hvis der foreligger tilstrækkelige indicier for, at der er begået en strafbar lovovertrædelse. $\S 170$, stk. 1, forpligter anklagemyndigheden til at rejse tiltale, hvis efterforskningen giver anledning hertil, det vil sige, hvis det forventes, at tiltalen vil føre til domfældelse. Der findes dog undtagelser fra denne pligt: For eksempel giver $\S \S 153$ ff. StPO og $\S 45$ Jugendgerichtsgesetz (JGG) anklagemyndigheden kompetence til under visse omstændigheder at undlade at rejse tiltale. Disse undtagelser fører til den vurdering i litteraturen, at opportunitet 
spiller en stor rolle i praksis, og til en strid om, hvordan det reelle forhold mellem opportunitet og legalitet er i det tyske system."

Spørgsmålet om forholdet mellem de to principper er afgørende, fordi legalitetsprincippet traditionelt opfattes som en garant for en rechtsstaatliches Verfahren, altså en straffeproces, som er i overensstemmelse med fundamentale retsstatslige principper. Men i tysk perspektiv er legalitet og opportunitet ikke alene en strafferetlig eller procesretlig problemstilling, men i høj grad også en forfatningsretlig. Den tyske forfatningsdomstol (Bundesverfassungsgericht $(B \operatorname{Verf} G)$ ) har i flere domme beskæftiget sig med spørgsmål, som vedrører opportunitet og legalitet i strafferetsplejen. I $B \operatorname{VerfGE} 46,214$ (s. $222 \mathrm{f}$.) siger forfatningsdomstolen, at det er statens pligt at retsforfølge straffelovovertrædelser konsekvent for dermed at sikre borgernes sikkerhed og lige behandling af lovovertrædere. Dette anses af legalitetsprincippets tilhængere som et stærkt argument mod opportunitet i strafferetsplejen. Men omvendt udelukker Bundesverfassungsgericht ikke opportunitet. I den samme afgørelse fastslår domstolen, at den generelle forpligtelse til at retsforfølge lovovertrædelser ikke udelukker lovregulerede undtagelser fra påtalepligten. I en senere afgørelse, den såkaldte "Cannabis Entscheidung" ("cannabis dom"), BVerfGE 90, 145, gik forfatningsdomstolen videre. Her stod domstolen over for spørgsmålet om, hvorvidt generel kriminalisering af blandt andet omgang med små mængder cannabis til uregelmæssigt, eget forbrug er en krænkelse af de forfatningsretlige principper om, at strafferetten kun må bruges som "ultima ratio" (sidste middel), og at straffetruslen skal stå i rimeligt forhold til de samfundsværdier, som ønskes beskyttet ("Übermaßverbot"). Retten konkluderede i sin meget omtalte dom, at staten kun kan benytte sig af en omfattende straftrussel for omgang med cannabis, hvis den samtidig accepterer muligheden for at undlade retsforfølgningen af forbrugeren, og denne mulighed bliver brugt i konkrete sager. Dommens konsekvens er, at anklagemyndigheden i sager vedrørende uregelmæssigt forbrug af små mængder ikke alene har kompetence til at frafalde tiltalen, men ligefrem er forpligtet til det. ${ }^{12}$

Spørgsmålet om forholdet mellem legalitet og opportunitet i det tyske retssystem er altså komplekst. En analyse af de procesretlige bestemmelser i lyset af forfatningsdomstolens udtalelser fører til den antagelse, at legalitetsprincippet er hovedreglen i det tyske system, mens opportunitet er den lovfæstede undtagelse i afgrænsede tilfælde. Dette er dog relativt, idet opportunitetsmulighederne flere gange er udvidet af lovgiveren, og opportunitetsbestemmelserne anvendes i dag i stort omfang. Således førte 32,2 \% af anklagemyndighedens afgørelser i sager, hvor gerningspersonen var fundet, i 1998 til afslutning af sagen af opportunitetsgrunde. I 1981 afsluttede anklagemyndigheden derimod kun $16,3 \%$ af sine sager med denne begrundelse. ${ }^{13}$

Når Danmark kategoriseres som et land, der bygger på opportunitetsprincippet, skyldes det to forhold: For det første findes der ingen udtrykkelig bestem- 
melse i retsplejeloven, som kunne svare til § 170, stk. 1, StPO, der forpligter anklagemyndigheden til at rejse tiltale, når der foreligger tilstrækkeligt bevis. For det andet giver rpl § 722 anklagemyndigheden forskellige muligheder for at frafalde tiltalen. Det er især den vidtgående opportunitetsbestemmelse i rpl $\S 722$, stk. 2, som forklarer kategoriseringen. Imidlertid anses denne kategorisering i Danmark ikke som særlig indholdsrig. ${ }^{14}$ Gorm Toftegaard Nielsen argumenterer for, at det i sidste ende er formålsløst at diskutere, hvilken etikette der skal sættes på det danske system. Det afgørende er for ham, at lovens udgangspunkt er, at der skal rejses tiltale, hvis der foreligger fornødent bevis, og at tiltalefrafald har undtagelseskarakter. ${ }^{15}$

Det er ikke muligt at give et fuldstændigt overblik over anvendelse af tiltalefrafaldet i dansk praksis: I kriminalstatistikken for 1999 anføres, at "tiltalefrafald" udgør $1,9 \%$ af politets, anklagemyndighedens og domstolens afgørelser. Kategoriseringen af afgørelsesformer i statistikken er imidlertid ikke konsekvent, idet den ikke følger retsplejelovens struktur. Også i kategorien "tiltale undladt", som udgør 9,5\% af afgørelserne, og som blandt andet omfatter påtaleopgivelse efter rpl $\S 721$, registreres nogle afgørelser efter rpl $\S 722$ og $\S 723$. Tiltalefrafalds andel af det samlede antal afgørelser ligger således mellem 1,9\% og $11,4 \% .^{16}$

\section{Forskelle og ligheder mellem det danske og det tyske system}

Et første blik på det danske og det tyske strafferetssystem afslører altså, at til trods for forskellig kategorisering betragtes legalitet i begge lande som hovedregel i spørgsmålet om tiltalerejsning og opportunitet som en undtagelse, der kræver lovhjemmel. Er det derfor ikke nærliggende at antage, at forskellen mellem det tyske og det danske retssystem i sidste ende er mindre, end først antaget?

Det er imidlertid iøjnefaldende, at spørgsmålet om legalitet og opportunitet $\mathrm{i}$ strafferetsplejen indtager en central rolle i den retsvidenskabelige debat i Tyskland, medens samme emne ikke fylder meget i danske debatter. Heri kan der ses et indicium for den antagelse, at der findes en grundlæggende forskel mellem det tyske og det danske retssystem. Set med danske øjne bliver det tyske retssystem ofte opfattet som stærkt dogmatisk orienteret, omvendt oplever den tyske observatør det danske retssystem som meget pragmatisk. ${ }^{17}$ Denne forskel beror ikke kun på det legislative grundlag i de to lande, men i langt højere grad på det, den retssociologiske forskning kalder "retskultur". Begrebet "retskultur" er dog ikke éntydigt defineret i litteraturen. ${ }^{18}$ Dog findes en vis enighed om, at det $\mathrm{i}$ hvert fald omfatter værdiforestillinger og holdninger, som danner grundlaget for retssystemet, eller som påvirker rettens anvendelse i praksis. ${ }^{19}$

I den analyse, som foretages her, indgår således, udover de to landes lovgrundlag og fortolkning, erfaringer vedrørende reglernes anvendelse i praksis og de faktorer, som påvirker anvendelsen. Der vil ikke være tale om en 
fuldstændig komparativ analyse, men en analyse af udvalgte centrale aspekter. Udvælgelsen er sket på grundlag af erkendelser vundet i min tyske doktorafhandling ${ }^{20}$ og i ønske om at anskueliggøre nogle væsentlige ligheder og forskelle mellem det tyske og det danske straffeprocessystem.

\section{Lovgrundlaget for opportunitetsafgørelser}

I begge retssystemer gælder princippet om, at betingelserne for ifaldelse af straffeansvar og de mulige straffe skal være reguleret ved lov. ${ }^{21}$ Straffeprocesret er det retlige virkemiddel til regulering af proceduren for anvendelse af den materielle strafferet. Procesretten skal sikre, at sagsbehandlingen og domfældelse - eller anden afslutning - sker i overensstemmelse med generelle retsstatslige principer og i øvrigt med gældende lov. ${ }^{22}$

I Tyskland er de fleste undtagelser fra anklagemyndighedens påtalepligt i Strafprozessordnung normeret, men der findes særlige bestemmelser for eksempel i lovgivningen om straffesager mod unge, $\S 45 J G G$, og i narkotikalovgivningen, § 31 a Betäubungsmittelgesetz $(B t M G)$. I Danmark er hjemmelsgrundlaget for tiltalefrafald samlet i $\mathrm{rpl} \S 722$. I begge lande beskriver reglerne adskillige situationer, i hvilke anklagemyndigheden kan frafalde tiltale. For begge retssystemer gælder, at nogle af reglerne indeholder udtrykkelige betingelser for at frafalde tiltale, mens andre åbner for et betydeligt skøn. ${ }^{23}$ I Danmark findes i rpl $\S 722$, stk. 2, en hjemmel til at frafalde tiltale, som giver anklagemyndigheden en vidtgående skønsbeføjelse. En tilsvarende hjemmel findes ikke i Tyskland.

Lovgivningen hjemler i begge lande mulighed for at frafalde tiltale med og uden vilkår. ${ }^{24} \mathrm{I}$ det tyske system benyttes vilkår i situationer med ikke særlig alvorlig kriminalitet (Vergehen, § 12 Strafgesetzbuch (StGB)), hvor anklagemyndigheden formoder, at den offentlige interesse $\mathrm{i}$, at lovovertrædelsen bliver retsforfulgt, kan tilgodeses ved opfyldelsen af vilkår. ${ }^{25}$ De mulige vilkår er udtrykkeligt nævnt i loven, og det mest anvendte er betaling af et af anklagemyndigheden fastlagt pengebeløb til en velgørende organisation eller til statskassen $(\S 153 \mathrm{a}$, stk. $1 \mathrm{nr} .2 \mathrm{StPO}){ }^{26}$

I Danmark fastsættes vilkår efter $\mathrm{rpl} \S \S 722 \mathrm{og} 723$. Det virkelige interessante i denne sammenhæng - igen ud fra en tysk synsvinkel - er imidlertid ikke lovgrundlaget for tiltalefrafald med vilkår, men hvordan der udvikles en praksis. Især udviklingen af praksis vedrørende unge lovovertrædere er et godt eksempel for forskellen: Baggrunden for udviklingen på området er, at der i Danmark - i modsætning til Tyskland - ikke eksisterer et særlig straffe- og proceduresystem for unge. I Danmark har man i stedet enkelte særlige lovbestemmelser vedrørende unge, hvori der tages højde for de unges særlige behov, blandt andet ved at åbne mulighed for at vælge en mildere reaktion. For eksempel hjemler rpl $\S 722$, stk. 1 , nr. 2 og nr. 3 muligheden for tiltalefrafald med vilkår i sager mod unge lovovertrædere. I praksis sker vilkårsfastsættelsen i disse tilfælde imidlertid ikke alene inden for reglerne i rpl $§ 722$, stk. 1 , nr. 2 og nr. 3, men ofte i 
form af en ungdomskontrakt. Ungdomskontrakten er en reaktionsform, som ikke er omtalt $i$ hverken retsplejeloven eller andre love, men som ifølge Rigsadvokatens Meddelelse 7/1998 (Behandlingen af unge lovovertrædere) som regel anvendes, hvis sagen mod den unge skal afsluttes med tiltalefrafald med vilkår. Teknisk set sker behandlingen af sagen i forbindelse med ungdomskontrakten som et ordinært tiltalefrafald med vilkår efter rpl § 722, stk. 1, nr. 2 eller nr. 3 og rpl $\S 723$. Forskellen til et ordinært tiltalefrafald er imidlertid, at vilkårene beskrives i en kontrakt, som gennemgås og underskrives i et særligt møde mellem anklagemyndigheden, den unge, dennes værge og en medarbejder fra de sociale myndigheder. ${ }^{27}$ Ungdomskontrakten skal derefter godkendes af retten, og den unge skal under retsmødet afgive tilståelse.

Introduktionen af ungdomskontrakter tog i slutningen af 80'erne sit udgangspunkt i en grundig debat i Folketinget. Debatten omhandlede blandt andet nye reaktionsformer over for ungdomskriminalitet og resulterede $i$ en afgrænset forsøgsordning med ungdomskontrakter i udvalgte politikredse. Forsøgsordningen var baseret på en Folketingsbeslutning. ${ }^{28}$ Selv om ungdomskontrakten altså har været genstand for en indgående behandling i Folketinget, blev den landsdækkende introduktion af denne reaktionsform ikke foretaget ved lov. Den i dag gældende praksis blev i stedet del af den danske strafferetspleje gennem Rigsadvokatens Meddelelse 7/1998, der nøje beskriver, i hvilke tilfælde ungdomskontrakten skal anvendes, og hvordan den i praksis skal gennemføres. ${ }^{29}$

Eksemplet vedrørende ungdomskontrakten viser, at spørgsmålet om undtagelser fra anklagemyndighedens påtalepligt kan i Danmark ikke alene besvares på baggrund af lovgrundlaget. Loven synes at give rammen for afgørelserne, og denne udfyldes og udvikles herefter i praksis.

Et andet eksempel findes i forbindelse med rpl § 722, stk. 1, nr. 1. Denne bestemmelse tillader anklagemyndigheden at frafalde tiltalen ved mindre lovovertrædelser, som kun har en ringe strafværdighed og kun straffes med bøde. I praksis kan et tiltalefrafald i medfør af $\mathrm{rpl} \S 722$, stk. $1 \mathrm{nr} .1$ imidlertid forbindes med en (skriftlig) advarsel fra politiet. ${ }^{30}$ Denne form for advarsel er ikke omtalt $\mathrm{i}$ lovgivningen, her omtales udelukkende advarsler, der tildeles i retten (rpl $\S$ 937). Igen er det rigsadvokatens interne bestemmelser, der åbner muligheden og som bestemmer, i hvilke situationer den anvendes. ${ }^{31}$

Fra en tysk synsvinkel er det ikke overraskende, at man i Danmark bruger reaktionsformer som advarsel og ungdomskontrakt. Det særlige ved det danske system er derimod, at etablering og udvikling af reaktionsformer sker i anklagemyndighedens eget regi.

En tilsvarende udvikling ses ikke i Tyskland. Bestemmelserne vedrørende opportunitetsafgørelser giver anklagemyndigheden et betydeligt spillerum for at træffe afgørelser og foretage prioriteringer i sit strafforfølgningsarbejde. Anklagemyndigheden udnytter dette spillerum i stort omfang i praksis - nogle mener endda $\mathrm{i}$ alt for stort omfang $\mathrm{g}^{32}-$, men dette betyder ikke, at den tager 
initiativ til at introducere egne reaktionsformer i strafferetsplejen.

Den retsskabende funktion, som den danske anklagemyndighed (på rigsadvokatens niveau) har, er til en vis grad hjemlet i retsplejeloven. I medfør af rpl $\S$ 722 , stk. 1, nr. 7 kan tiltalen nemlig frafaldes, hvis muligheden fremgår af bestemmelser udstedt af justitsministeren eller rigsadvokaten. Lovgiveren har dermed givet hjemmel til begge til at konkretisere eller udvide bestemmelserne vedrørende tiltalefrafald. I praksis har justitsministeren delegeret sin kompetence til rigsadvokaten, som i "Bekendtgørelse $\mathrm{nr}$. 816/2000 om politimestrenes og statsadvokatens adgang til at frafalde tiltale" definerer yderligere muligheder for tiltalefrafald. En tilsvarende bemyndigelse findes ikke i tysk ret.

Men den retsskabende funktion af den danske anklagemyndighed er ikke nødvendigvis begrænset af den i retsplejeloven hjemlede kompetence. Udover de her nævnte eksempler omtaler Henricson forskellige områder, hvor der i praksis anvendes tiltalefrafald, uden (klart) lovgrundlag. ${ }^{33}$ Henricson konkretiserer ikke, hvor udbredt dette er, men set fra en tysk synsvinkel er det værd at notere, at en dansk vicepolitimester omtaler ikke-lovregulerede former af tiltalefrafald, uden at det fremprovokerer særlige reaktioner. En lignede hændelse vil i Tyskland med al sandsynlighed medføre heftig debat om overskridelsen af anklagemyndighedens kompetence.

\section{Opportunitetsafgørelser $i$ en bredere kontekst}

Vurderingen af opportunitets- eller legalitetsprincippets rolle i strafferetsplejen og hermed anklagemyndighedens funktion hverken kan eller bør alene ske på grundlag af tiltalefrafaldsbestemmelserne. I begge lande eksisterer opportunitetsmulighederne i et komplekst system af afgørelsesmuligheder. For at få et reelt indtryk af mulighederne for opportunitetsafgørelser i de to lande skal hvert regelsæts kontekst inddrages.

Vil man for eksempel som dansk forsker undersøge, om der i Tyskland findes en hjemmel til at frafalde tiltalen i mindre straffesager, som svarer til reglen i rpl $\S 722$, stk. 1, nr. 1, så er det ikke tilstrækkeligt at beskæftige sig med reglerne i straffeprocessen (for eksempel $\S 153$, stk. 1, StPO). I Tyskland eksisterer en todeling af lovovertrædelser, hvilket betyder, at ikke alle lovovertrædelser omfattes af selve strafferetten. Mindre lovovertrædelser, såkaldte Ordnungswidrigkeiten, behandles uden for den egentlige strafferet i et administrativt system og kan kun straffes med en slags bøde (Geldbuße). ${ }^{34}$

Nogle af de mindre lovovertrædelser, som i Danmark kan blive afsluttet efter rpl § 722, stk. 1, nr. 1, som for eksempel mindre færdsels- og miljøsager eller sager vedrørende overtrædelser af lukkeloven, behandles således i Tyskland slet ikke som straffesager, men som Ordnungswidrigkeiten. ${ }^{35}$ Ved forfølgningen af disse gælder imidlertid et vidtgående opportunitetsprincip, som udtrykkes på to måder: For det første fremgår det af $\S 47$, stk. 1, Gesetz über Ordnungswidrigkeiten $(\mathrm{OWiG})$, at forfølgning af Ordnungswidrigkeiten ligger i myndighe- 
dens $^{36}$ "pligtopfyldende skøn" ("plichtgemäße Ermessen"). For det andet er alle Ordnungswidrigkeiten-bestemmelser formuleret på en sådan måde, at lovovertrædelsen kan straffes med Geldbuße. I modsætning hertil er straffebestemmelserne altid formuleret således, at lovovertræderen bliver straffet med bøde og/eller fængsel. Undladelse af imperativ form i Ordnungswidrigkeiten-bestemmelserne fortolkes således, at anvendelse af en sanktion ikke er obligatorisk, men en mulighed. ${ }^{37}$

Med den tyske todeling omfatter straffeprocessen her reelt kun en delmængde af, hvad den danske omfatter. Denne erkendelse er vigtig for en samlet forståelse af, hvilke overtrædelser det - efter dansk opfattelse måske lidt stive - tyske legalitetsprincip reelt rammer. For eksempel rammer det ikke det i praksis store område af små færdselssager.

Også det omvendte perspektiv bekræfter, at det er nødvendigt at inddrage forskellige aspekter i sammenligningen mellem den tyske og den danske anklagemyndigheds rolle i strafferetsplejen. Ønsker en tysk forsker at få et dækkende overblik over anklagemyndighedens mulighed for selv at afslutte sager med en bødelignende reaktion svarende til § $153 \mathrm{a}$, stk. 1, nr. 2 StPO, må han/hun inddrage andre regler end den mest nærliggende parallel (rpl § 723, stk.1, nr.1). Uden blik for $\mathrm{rpl} \S 924$, som indeholder hjemmel til, at anklagemyndigheden i visse tilfælde kan forelægge borgeren en bøde, som vedkommende kan betale og derved undgå en domstolsbehandling, mangler man en ikke ubetydelig dimension i det danske bødesystem.

Baggrunden for en tysk interesse i afgørelsesmuligheder, som tillader, at anklagemyndigheden bestemmer over en bøde (eller en bødelignende reaktion), er, at den tyske anklagemyndighed gerne bruger bødevilkåret efter $§ 153 \mathrm{a}$, stk. 1 , nr. 2 StPO som middel til at afslutte sager om småkriminalitet. ${ }^{38}$ På den anden side har den ud over denne regel ikke kompetence til at slutte sagen under forudsætning af, at vedkommende betaler et pengebeløb.

Den tyske anklagemyndighed kan i stedet for at rejse tiltale forberede en såkaldt Strafbefehl ( $\S 407$ ff. StPO), i hvilken følgerne af lovovertrædelsen fastsættes. I Strafbefehl, som ikke kan anvendes ved meget alvorlige lovovertrædelser ( $§ 407$, stk. 1 StPO), kan der blandt andet fastsættes en bøde eller, under visse omstændigheder, betinget fængsel i op til et år. ${ }^{39}$ Imidlertid er det ikke anklagemyndigheden, som træffer den endelige beslutning om vedtagelsen af Strafbefehl, men domstolen. Anklagemyndigheden tager initiativ til denne afgørelsesform og foreslår sanktionen, men det er forbeholdt domstolen at bestemme, om Strafbefehl skal gennemføres eller ej. Den sigtede kan modsætte sig Strafbefehl, hvilket betyder, at der gennemføres en almindelig domstolsforhandling, hvor Strafbefehl bruges som anklageskrift. Reagerer vedkommende ikke inden for 2 uger, får en Strafbefehl retskraft og er dermed ligestillet med en dom $(\S 410$ StPO). 
Det er altså ikke Strafbefehls-muligheden, som giver den tyske anklagemyndighed kompetence til selvstændigt at anvende en bødelignende reaktion. Også i forbindelse med et tiltalefrafald med vilkår i medfør af $\S 153 \mathrm{a}$, stk. 1, nr. 2 StPO er anklagemyndighedens bemyndigelse begrænset: Bestemmelsen forudsætter som regel, at domstolen godkender vilkåret. Baggrunden for denne godkendelse er, at det anses for domstolenes monopol at fastsætte enhver strafferetlig sanktion eller sanktionslignende reaktion. ${ }^{40}$ Men samtidig ser man også i det tyske system det praktiske i, at små sager kan afgøres uden den fulde strafferetlige procedure og uden at involvere domstolen. Derfor indeholder $\S 153 \mathrm{a}$, stk. 1, s. $6 S t P O$ (i forbindelse med $\S 153$, stk. 1, s. $2 S t P O$ ) en undtagelse fra godkendelseskravet. Anklagemyndigheden kan slutte sagen med vilkår uden rettens deltagelse, hvis sagen vedrører en mindre alvorlig lovovertrædelse,$^{41} \mathrm{og}$ hvis følgerne af lovovertrædelsen er af mindre karakter. Det er altså kun i disse tilfælde, at man kan konkludere, at den tyske anklagemyndighed har en selvstændig sanktionskompetence. ${ }^{42}$

Anvendelse af tiltalefrafald med vilkår er i Tyskland imidlertid afhængig af, at den sigtede medvirker i afgørelsesformen, idet § 153a, stk. 1, StPO kræver, at han/hun erklærer sig enig i afslutningsformen. Kravet om den sigtedes samarbejde anses som legitimation for, at domstolen ikke altid involveres i fastsættelsen af reaktionen, fordi afgørelsen skal baseres på en konsensus mellem anklagemyndigheden og den sigtede. ${ }^{43}$

Også vedrørende tiltalefrafald med vilkår i Danmark er det reelt en forudsætning, at den pågældende medvirker, idet denne afgørelsesform kun kan vælges, hvis der afgives en uforbeholden, bestyrket tilståelse i retten, rpl § 723, stk. 2. Derudover kræves der for bødevilkåret efter $\mathrm{rpl} \S 723$, stk. 1, nr. 1, at den sigtede vedtager at betale bøden. En vigtig forskel til det tyske system er imidlertid, at det for ethvert tiltalefrafald med vilkår forudsættes, at domstolen godkender vilkårene. Domstolen har ingen aktiv rolle i denne procedure, fordi den ikke selv kan bestemme eller forandre vilkår, men uden dens deltagelse kan tiltalefrafald med vilkår ikke gennemføres. Dette betyder, at der i forbindelse med denne afslutningsform ikke er tale om en selvstændig sanktionskompetence hos anklagemyndigheden.

Men den danske anklagemyndighed har med bødeforelægget en afgørelsesform til rådighed, som indebærer en selvstændig sanktionsfunktion. I medfør af rpl § 924 har den kompetence til at fastsætte en bøde i et bødeforelæg, hvis vedkommende erklærer sig skyldig i lovovertrædelsen og vedtager bøden. Afgørelsesformen kan kun anvendes i sager af mindre alvorlig kriminalitet, idet loven kræver, at lovovertrædelsen ikke ville medføre højere straf end bøde ( $r p l ~ § 924$, stk. 1). Bødeforelæg er en afgørelsesmåde, som foregår mellem anklagemyndigheden og den pågældende, og kan kun gennemføres, hvis han/hun medvirker aktivt. I modsætning til de tyske former for forkortede procedurer til fastlæggelsen af en bøde eller en bødelignende sanktion, deltager domstolene aldrig i bødeforelæg. Kun hvis den pågældende ikke ønsker at medvirke, kommer sagen 
til domstolsbehandling.

Bødeforelæg spiller en stor rolle i dansk praksis: I 1999 endte $71,9 \%$ af politiets, anklagemyndighedens og domstolens afgørelser (overtrædelse af straffeloven og særlove) med en bøde. 53,5\% af alle afgørelser skete som bødeforlæg. ${ }^{44}$ Dermed har anklagemyndigheden i lidt over halvdelen af alle strafferetlige afgørelser bestemt sanktionen, uden at domstolen var involveret.

Det kan altså konkluderes, at der i begge retssystemer findes en kompetence for anklagemyndigheden til selvstændigt, dvs. uden rettens deltagelse, at slutte sager med fastsættelsen af (i Tyskland: blandt andet) en bøde. I begge systemer er reaktionsformerne afhængig af, at den pågældende accepterer bøden, og forskellen ligger ikke primært $i$ indholdet af afslutningsformen, men den retslige kvalifikation. Med til sammenligningen hører også, at en del af de lovovertrædelser, som sluttes med bødeforelæg i Danmark, ikke er omfattet af strafferetten i Tyskland og kan der straffes som Ordungswidrigkeit med Geldbuße. Proceduren i disse sager er, at forvaltningsmyndigheden fastsætter sanktionen i en skrivelse (Bußgeldbescheid, $\S 66 \mathrm{OWiG}$ ), og at domstolen kun beskæftiger sig med sagen, hvis vedkommende modsætter sig afgørelsen ( $\S 67 \mathrm{ff}$. OWiG).

\section{Styring af opportunitetsafgørelser}

Spørgsmålet om anklagemyndighedens kompetence til at træffe opportunitetsafgørelser er tæt knyttet til spørgsmålet om, hvilken retslig aktør i retssystemet der skal bestemme, hvornår og med hvilke følger straffesagen afsluttes. Dette aspekt indtager en fremtrædende position i den retsvidenskabelige diskussion i Tyskland vedrørende legalitet og opportunitet. Kritikken af de i loven hjemlede opportunitetsmuligheder peger især på, at disse overdrager anklagemyndigheden en funktion, som strider imod anklagemyndighedens egentlige opgave og domstolens monopol til at bestemme over straffastsættelsen. Kritikken vender sig især mod bestemmelsen i $\S 153 \mathrm{a}$, stk. 1, StPO, idet denne bestemmelse blandt andet giver mulighed for at frafalde tiltalen under fastsættelse af vilkår uden rettens deltagelse. Argumentet mod denne kompetence er, at den bryder med den egentlige kompetencefordeling i strafferetten, som forbeholder domstolen sanktionsfastsættelsen: Ved at frafalde tiltalen med vilkår virker anklagemyndigheden i sidste ende som "dommer før dommeren", hvilket anses for at være i strid med den tyske grundlov (Grundgesetz). ${ }^{45}$ Argumentet, at fremgangsmåden retfærdiggøres ved kravet om, at den sigtede er indforstået, bliver af kritikkerne mødt med en tvivl om, hvorvidt den sigtedes deltagelse $\mathrm{i}$ alle tilfælde kan betegnes som frivillig. ${ }^{46}$

Tilhængerne af opportunitetsmulighederne anser disse som et effektiv middel til at undgå unødvendige straffesager og til at afgøre mindre sager med forkortet procedure, svarende til sagens betydning. Mod denne opfattelse bliver det imidlertid anført, at disse afgørelsesformer ganske vist kan være praktiske, men i sidste ende forhindrer de, at en egentlig afkriminalisering sker. Derudover 
anføres det, at de medvirker til, at grænsen mellem det, som er strafbart, og det, som ikke straffes, bliver utydelig. ${ }^{47}$ Det billede, som diskussionen tegner, er, at tyskernes forhold til opportunitetsmulighederne er ambivalent, og at holdningerne ikke mindst er præget af forfatningsretlige overvejelser.

I Danmark fremprovokerer emnet ikke de store principielle diskussioner. I modsætning til Tyskland spiller - også i forbindelse med andre straffe(proces)retlige problemstillinger - forfatningsretslige argumenter og mere principielle overvejelser ikke en fremtrædende rolle i retslitteratur og retspraksis. Forskellen kan forklares med, at det er en del af dansk retstradition, at grundloven indtager en begrænset rolle $\mathrm{i}$ domstolens håndtering af strafprocessuelle problemstillinger ${ }^{48}$ og dermed også i litteraturen. I Tyskland anses det derimod som en del af forfatningsdomstolens opgave at behandle straffe(proces)retslige spørgsmål. Den forfatningsretslige vinkel på strafferetlige problemstillinger afspejler sig klart i den tyske retsvidenskabelige debat.

Uanset denne grundlæggende forskel i retskultur og -opfattelse har anklagemyndigheden dog i begge lande altså kompetence til at træffe opportunitetsafgørelser og, ved mindre lovovertrædelser, en selvstændig sanktionskompetence. Disse kompetencer rejser i den tyske litteratur (næsten nødvendigvis) spørgsmålet om styring og kontrol af anklagemyndighedens afgørelser.

I begge lande er anklagemyndigheden en hierarkisk opbygget forvaltningsmyndighed, hvor det højerestående niveau har en kontrol- og tilsynsfunktion over for de laverestående niveauer. Den højerestående anklager kan udstede generelle regler om, hvordan sager skal behandles, og kan gribe ind i konkrete sager. ${ }^{49}$ I Danmark er det først og fremmest rigsadvokaten, som med sine meddelelser styrer anklagemyndighedens brug af opportunitetsmulighederne og bødeforelæg og i visse tilfælde regulerer nye afgørelsesformer.

I Tyskland er styringen af anklagemyndighedens brug af opportunitetsmuligheder mere komplekst. Den tyske anklagemyndigheds organisation svarer til den tyske stats føderale organisation. Dette betyder, at der eksisterer såvel en føderal anklagemyndighed som en anklagemyndighed i de enkelte delstater. Den føderale anklagemyndighed tager sig kun af få alvorlige lovovertrædelser, mens delstaternes er ansvarlig for det store flertal af sager. Selvom lovgrundlaget for anklagemyndighedernes arbejde er føderalt, er der altså ikke tale om en landsdækkende og centralt styret myndighed. Der kan ikke udstedes generelle interne regler for anvendelsen af loven, fordi der ikke findes en fælles overordnet anklager, svarende til rigsadvokaten i Danmark. I delstaterne er det delstatens justitsminister, som fører tilsyn med anklagemyndigheden. Interne regler om lovens fortolkning og udøvelsen af anklagemyndighedens opgaver bliver udstedt af Generalstaatsanwalt, som er den øverste anklager i en retskreds af en Oberlandesgericht. Oberlandesgericht er det øverste niveau i delstatens domstolsorganisation, hvoraf der kan imidlertid være flere i en delstat og dermed flere Generalstaatsanwälte. ${ }^{50}$ 
Anklagemyndighedens føderale struktur er grunden til, at det i Tyskland kan være vanskeligt at identificere en klar strafforfølgningspolitik. ${ }^{51}$ Problemet blev også set af Bundesverfassungsgericht i dens tidligere omtalte "cannabisdom" (BVerfGE 90,145): Domstolen understregede her, at det er delstaternes forpligtelse at sikre en ens anvendelse af opportunitetsgrunde. I forbindelse med cannabissagen drejede det sig konkret om spørgsmålet, hvordan der i praksis fortolkes "små mængder", som er en forudsætning for en afslutning af sager efter $\S 31 \mathrm{a} \mathrm{BtMG}$.

Domstolens krav baseres blandt andet på overvejelsen om, at delstaterne kan sikre en ensartet strafforfølgningspolitik via ens formulerede instrukser/vejledninger til deres anklagere. ${ }^{52}$ I praksis imødekommer delstaterne kun delvist domstolens krav. En analyse af behandlingen af narkotikakriminalitet i de enkelte delstater viser, at de regionale vejledninger for håndtering af narkosager stadigvæk er ret forskellige med hensyn til, hvad der forstås ved "små mængder", og hvordan behandlingen af unge og gentagelsestilfælde skal foregå. Samtidig hermed viser analysen af praksis dog, at behandlingen af cannabissager i betydelig grad er ens i delstaterne, undtagen i forbindelse med gentagelsessager. Analysen af håndteringen af sager i forbindelse med "hårde stoffer" viser derimod i praksis store forskelle mellem delstaterne, hvorfor der konkluderes, at der er behov for lovgiverens indblanding. ${ }^{53}$

Den manglende mekanisme til at sikre, at opportunitetsmulighederne bliver ens anvendt i Tyskland, er en del af forklaringen på, hvorfor store dele af den juridiske litteratur er meget kritisk indstillet over for opportunitet i retsplejen. Danmark er derimod et betydeligt mindre land og anklagemyndighedens centralistiske organisation gør, at dens arbejde virker mere gennemskueligt. I denne sammenhæng bliver det påpeget, at der i Danmark undgås mytedannelse omkring tiltalefrafald, fordi praksis offentliggøres i årsberetningerne.${ }^{54}$ Det informative indhold af anklagemyndighedens årsberetning i forbindelse med opportunitetsafgørelser er imidlertid ikke længere særlig stor, fordi det efter ændringen af tiltalekompetencen i $1992{ }^{55}$ ikke længere er rigsadvokaten, som træffer afgørelse efter $\S 722$, stk. 2.

\section{Konklusioner}

Sammenligningen af de her præsenterede aspekter af det tyske og det danske straffeprocessystem viser, at begge systemer baserer sig på nogle fælles grundsætninger, men samtidig kan der konstateres væsentlige forskelle. Begge systemer befinder sig et sted mellem et rendyrket legalitetsprincip og et rendyrket opportunitetsprincip. Forskellene mellem de to lande ligger ikke udelukkende i det normative grundlag, men også i bestemmelsernes fortolkning og anvendelse i praksis.

En vigtig konklusion er, at der i begge lande eksisterer afgørelsesformer, som muliggør, at anklagemyndigheden kan afslutte mindre sager uden forelæggelse 
for domstolene. Dette kan foregå med eller uden bøde eller en bødelignende reaktion. Forskellen mellem retssystemerne ligger i denne sammenhæng ikke primært $\mathrm{i}$ indholdet af disse afgørelsesmuligheder, men i den retslige konstruktion.

En anden forskel vedrører spørgsmålet om, hvorvidt anklagemyndigheden selv udvikler reaktionsformer, og hvordan opportunitetsafgørelser kan styres. Ens for begge systemer er, at opportunitetsmulighederne i et vist omfang er forbundet med en reducering af domstolens kompetence. Lovgiverens beslutning om at overdrage anklagemyndigheden kompetence til at træffe opportunitetsafgørelser betyder, at det ikke er forbeholdt domstolene at afgøre disse straffesager.

Den her foretagne sammenligning har selvfølgelig kun berørt nogle af de aspekter, som spiller en vigtig rolle i forbindelse med legalitets- og opportunitetsprincippets rolle i strafprocessen. Et andet relevant spørgsmål kunne eksempelvis være relationen og kompetencefordelingen mellem anklagemyndigheden og politiet, samt om politiet kan træffe egne opportunitetsafgørelser.

På baggrund af de påpegede forskelle må det antages, at et europæisk samarbejde på strafferetsområde kan blive vanskeligt. Komparationen har vist, at selv retssystemer, som ligger ret tæt på hinanden - som Tyskland og Danmark på mange måder gør - har nogle grundlæggende forskellige opfattelser af anklagemyndighedens rolle i straffeprocessen. Forskellen kan ikke kun udlignes på det normative plan, fordi det i høj grad handler om forskellige retstraditioner og opfattelser af, hvilken rolle anklagemyndigheden skal have i straffeprocessen.

Spørgsmålet er derfor, hvordan man vil prøve at forene disse forskellige opfattelser i for eksempel en mulig europæisk anklagemyndighed. Derudover kan der spørges, om et europæisk samarbejde på strafferetsområdet, som går ud på at harmonisere de nationale strafferetssystemer, er ønskeligt eller ej? Ethvert retssystem finder de løsningsmodeller, som passer bedst til systemet. De enkelte komponenter i systemet er i de fleste tilfælde resultatet af en længerevarende udvikling. Hvis man vil forandre et (vel)fungerende system, så skal man have en klar forestilling om, hvilket formål det skal tjene, og hvordan man vil gennemføre forandringen uden at ødelægge systemets balance.

På den anden side står argumentet om nødvendigheden af en koordineret bekæmpelse af kriminalitet i EU, for eksempel i forbindelse med grænseoverskridende kriminalitet som menneskehandel eller terrorisme. ${ }^{56}$ Et andet aspekt af udefra kommende påvirkninger på de enkelte retssystemer er samarbejdet i Europarådet og Den Europæiske Menneskerettighedskonvention, som (blandt andet) indeholder klare principper for strafferetsplejen, og som er sikret via et system, hvor krænkelserne kan påklages til Menneskerettighedsdomstolen i Strasbourg. ${ }^{57}$

Europæiske påvirkninger på nationale retssystemer og ønsket om samarbejde på europæisk plan er en realitet. Men spørgsmålet om, hvor udviklingen går 
hen, er stadigvæk ubesvaret. Der er derfor et behov for at debattere spørgsmålet, både på nationalt og europæisk plan, og for at lære mere om forskelle og ligheder mellem de involverede retssystemer.

\section{LITTERATUR}

Aulinger, Susanne: § 31a BtMG - Der Auftrag des BverfG und die Rechtswirklichkeit, Neue Zeitschrift für Strafrecht (NStZ) 1999, s. 111-116.

Blankenburg, Erhard: Legal Cultures on Every Conceptual Level, i: Globalization and Legal Cultures - Oñati Summer Course 1997, Feest Johannes (udgiver), 1999.

Elholm, Thomas: Nytter EU's harmonisering af strafferetten?, Lov \& ret 05/2001, s. 21-25.

Erb, Volker: Legalität und Opportunität, 1999.

Erster Periodischer Sicherheitsbericht: Bundesministerium des Inneren / Bundesministerium der Justiz (udgiver), 2001.

Fionda, Julia: Public Prosecutors and Discretion; A Comparative Study, 1995.

Friedman, Lawrence M.: Legal Culture and Social Development, Law and Society Review 4 (1969), s. $29-44$.

Gammeltoft-Hansen, Hans: Strafferetspleje I, 2. udgave, 1997.

Garde, Peter / Greve, Vagn / Langsted, Lars Bo: Criminal Law in Denmark, 1998.

Gessner, Volkmar: Global Approaches in the Sociology of Law: Problem and Challenges, Journal of Law and Society 22 (1995). S. 85-96.

Greve, Vagn: Det strafferetlige ansvar, 1999.

Hamm, Rainer: Mißbrauch des Strafrechts, Neue juristische Wochenschrift (NJW) 1996, s. 29812982.

Henricson, Ib: Politiret, 2. udgave, 1999.

Kausch, Erhard: Der Staatsanwalt - Ein Richter vor dem Richter?; Untersuchungen zu $\S 153$ a StPO, 1980.

KK-OWiG (-forfatter): Karlsruher Kommentar zum Gesetz über Ordnungswidrigkeiten, Boujong, Karlheinz (udgiver), 2000.

KK-StPO (-forfatter): Karlsruher Kommentar zur Strafprozeßordnung, Pfeiffer, Gerd (udgiver), 4. udgave, 1999.

Kommenteret retsplejelov: Bind III, 6. udgave, 1997.

Kriminalitet 1999: Danmarks Statistik, 2000.

Kyvsgaard, Britta: Undersøgelse af ungdomskontrakter, tillæg til Rigsadvokaten informerer nr. $2 / 2000$.

LR-StPO (-forfatter): Die Strafprozeßordnung und das Gerichtsverfassungsgesetz, Löwe, Ewald / Rosenberg, Werner (udgiver), 24. udgave, 2. bind, 1989.

Nelles, Ursula / Velten, Petra: Einstellungsvorschriften als Korrektiv für unverhältnismäßige Strafgesetze?, Neue Zeitschrift für Strafrecht (NStZ) 1994, s. 366-370.

Pott, Christine: Die Außerkraftsetzung der Legalität durch das Opportunitätsdenken in den Vorschriften der $\$ \S 154,154$ a StPO, 1996.

Ranft, Otfried: Strafprozeßrecht, 1991.

Rentzmann, William / Reimann, Johan: Samfundstjeneste og ungdomskontrakter - og andre samfundsaktioner og -foranstaltninger, 1994.

Roxin, Claus: Strafverfahrensrecht, 25. udgave, 1998.

SK-StPO (-forfatter): Systematischer Kommentar zur Strafprozessordnung und zum Gerichtsverfassungsgesetz, Rudolphi, Hans-Joachim (o.a.), $1998 \mathrm{ff}$.

Smith, Eva: Straffeproces, 3. udgave, 1999.

Toftegaard Nielsen, Gorm: Straffesagens gang, 2. udgave, 2001.

Vial, Enzo Luigi: Die Gerichtsstandswahl und der Zugang zum internationalen Zivilprozeß im 
deutsch-italienischen Rechtsverkehr, 1999.

Weigend, Thomas: Das "Opportunitätsprinzip "zwischen Einzelfallgerechtigkeit und Systemeffizienz, Zeitschrift für die gesamte Strafrechtswissenschaft (ZStW) 109 (1997), s. 103 - 121.

Zeigert, Konrad / Kötz, Hein: Einführung in die Rechtsvergleichung, 3. udgave, 1996.

\section{ANDRE KILDER OG DOMME}

Bekendtgørelse $n r$ : $816 / 2000$ om politimestrenes og statsadvokatens adgang til at frafalde tiltale af 29.08.2000.

Betaenkning nr.1066/1986: Bekæmpelse af økonomisk kriminalitet.

Betænkning nr.1194/1990: Betænkning om anklagemyndighedens struktur.

Bundestagsdrucksache (BT-Ds.) 14/4991 (= Forbundsdagens tidende).

Folketingstidende 1989-1990, F (bind VI og VII).

Rigsadvokatens meddelelse 14/1977 (RM 14/1977).

Rigsadvokatens meddelelse 16/1982 (RM 16/1982).

Rigsadvokatens meddelelse 7/1998 (RM 7/1998): "Behandlingen af unge lovovertrædere".

Rigsadvokaten, Vejledning om bødetakster i politisager (bødekatalog).

BVerfGE 46, 214 (Entscheidungen des Bundesverfassungsgerichts, bind 46, s. 214 ff.).

$B$ VerfGE 90, 145 (Entscheidungen des Bundesverfassungsgerichts, bind 90, s. 145 ff.).

\section{NOTER:}

${ }^{1}$ Fionda, s. 1 ff., som undersøger spørgsmålet i forhold til det engelske, tyske og hollandske retssystem.

${ }^{2}$ Elholm, s. $21 \mathrm{ff}$.

${ }^{3}$ Den tyske forbundsregering anser for eksempel de europæiske initiativer til oprettelsen af "EUROJUST" som en "mögliche Keimzelle" ("mulig spirecelle") til en fælles europæisk anklagemyndighed, BT-Ds.14/4991, s. 32 ff.

${ }^{4}$ Først i 1986 blev en egentlig anklagemyndighed ("Crown Prosecution Service") introduceret i det engelske/walisiske strafferetssystem, Fionda s. $14 \mathrm{ff}$.

${ }^{5}$ Se for eksempel det indgående studie af Erb, s. 21 ff. og s. 63 ff., der konkluderer, at forskellen ligger i den retlige styring og i strukturering af anklagerens afgørelse. Sammenfattende drejer det sig efter hans mening om et spørgsmål om "Ermessen" ("skøn"). Mod "Ermessen" som det afgørende kriterium af forskellen mellem legalitets- og opportunitetsprincip: SK-StPO-Weßlau, § $152 \mathrm{Rdnr} .7$ og Rdnr.32.

${ }^{6}$ Gammetoft-Hansen, s. 183, Langsted / Garde / Greve, s. 167.

7 "Materielle Betrachtungsweise": se Weigend, s. 105 ff. og Fionda, s. 8 f.

8 "Formelle Betrachtungsweise": se SK-StPO-Weßlau, § 152 Rdnr.25.

${ }^{9}$ Fionda, s. $8 \mathrm{ff}$.

${ }^{10}$ Fionda, s. 9, formoder, at det italienske retssystem kommer tættest på et legalitetsprincip i ren form, mens det hollandske system kan anses som det bedste eksempel på et udpræget opportunitetsprincip.

"Der findes for eksempel opfattelserne, at undtagelserne fører til en udtømning af legalitetsprincippet, at opportunitetstanken bliver overordnet legalitetsprincippet eller at for visse former af kriminalitet de facto anvendes opportunitetsprincippet, se Pott, s. 2 og 122 ff., Roxin, s. 86 og SK-StPOWeßlau, § 152 Rdnr.7 og Rdnr.32.

${ }^{12}$ Nelles / Velten, s. $366 \mathrm{ff}$.

${ }^{13}$ Disse tal vedrører kun anklagemyndighedens arbejde i delstaterne i Vesttyskland (uden SchleswigHolstein, Berlin og Hessen. Tallet for 1998 omfatter delvis information fra delstaterne for året 1997): Erster Periodischer Sicherheitsbericht, s. 347 f. (tabel 3.2.-1).

${ }^{14}$ For eksempel Gammeltoft-Hansen, s. 183 og Langsted / Garde/ Greve, s. 167.

${ }^{15}$ Toftegaard Nielsen, s. 109. 
${ }^{16}$ Kriminalitet 1999, s. 47. Konkretiseringen af indholdet af kategorierne skete med hjælp fra Ebbe Frørup fra Danmarks Statistik.

${ }^{17}$ I kurser om det tyske retssystem, hvilke jeg siden 1998 har undervist i på forskellige danske universiteter, bruger deltagerne tit begreber som "lovfikseret", "dogmatisk", "teoretisk" og "ikke særlig pragmatisk", hvis jeg beder dem om at beskrive det tyske retssystem. Vedrørende et tysk syn på det danske retssystem: Zweigert / Kötz, s. 34 und s. 41 f.

${ }^{18}$ De fleste definitionsforsøg tager udgangspunkt i Friedman, s. 34, der mener, at retssystemer er sammensat af tre komponenter: en "structural component" (dvs. retssystemets institutionelle ramme), en "substantive component" (dvs. skrevet og uskrevet retsregler), og en "cultural component" (dvs. værdiforestillinger og holdninger som er grundlaget for retssystemet). Mod Friedmans forståelse af "retskultur": Blankenburg, s. 11 ff. og Gessner, s. 89, som begge mener at retskultur omfatter alle komponenter af retssystemet.

${ }^{19}$ Vial, s. 28

${ }^{20}$ Afhandlingens titel er "Zwangloses Strafverfahren? - Verfahrensbeendigungen aus Gründen der Opportunität durch die Anklagebehörde in Dänemark aus deutscher Sicht". Afhandlingen udgives som bog i Tyskland i løbet af efteråret 2002.

${ }^{21} \mathrm{Strl} \S 1, \S 1 \mathrm{StGB}$ og art. 7, stk. 1 EMRK.

${ }^{22}$ Roxin, s. $1 \mathrm{ff}$.

${ }^{23}$ Gammeltoft-Hansen, s. 184, KK-StPO-Schoreit, § 153 Rdnr.2 und Ranft, s. 56 f.

${ }^{24}$ Med vilkår: $\S 153 \mathrm{a}$ StPO og rpl $\S 722$, stk.1, nr. 2 og nr. 3, rpl § 723.

${ }^{25}$ LR-StPO-Rie $\beta, ~ § 153 \mathrm{a}, \mathrm{Rdnr} .27 \mathrm{ff}$.

${ }^{26}$ Anvendelsen af dette vilkår i praksis kan illustreres ved retskredsen OLG Bremen: I 1992 (dvs. før indførelsen af et 5. muligt vilkår - deltagelse i et trafikseminar - i 1998) blev 2.462 sager afsluttet efter $\S 153 \mathrm{a}$ stk.1 StPO. Heraf var 2.212 sager, som havde betaling af en pengebeløb ( $\$ 153 \mathrm{a}$ stk. 1 nr.2) som vilkår. Året før blev 2.087 ud af 2.372 afsluttet med dette vilkår. Tallene stammer fra den interne anklagemyndighedsstatistik for delstaten Bremen (Statistisches Landesamt Bremen, unveröffentlichte Staatsanwaltschaftsstatistik).

${ }^{27}$ Om indholdet af ungdomskontrakter i praksis se Kyvsgaard, s. 6 f. og RM 7/1998, s. 10 ff.

${ }^{28}$ Rentzmann / Reimann, s. 37 ff. og Folketingstidene1989-1990, F bind VI, sp.8699-8730 og F bind VII, sp.10472-10484.

${ }^{29}$ RM 7/1998, s. 8 ff.

${ }^{30}$ Kommenteret retsplejelov, bind III, s. 31 og Toftegaard Nielsen, s. 110 ff.

${ }^{31}$ Tidligere anvendtes politiets advarsel for eksempel i visse butikstyveri-sager (RM 14/1977 og RM 16/1982). I dag bliver disse sager først og fremmest afgjort med bødeforelæg, men i rigsadvokatens såkaldte "bødekatalog" ("Vejledning om bødetakster i politisager") gives der stadigvæk hjemmel til at afslutte sager med advarsel (punkt 3.2.-1). Også i sager mod unge kan der bruges advarsel, RM 7/1998, s. 7 f.

${ }^{32}$ Se den tyske strid om spørgsmålet, om opportunitetsmulighederne i praksis udhuler legalitetsprincippet, slutnote 11 .

${ }^{33}$ Henricson, s. 178 ff. nævner som uregulerede former af tiltalefrafald for eksempel tiltalefrafald på grund af lighedshensyn, på grund af lange sagsbehandling og indirekte tiltalebegrænsning.

${ }^{34}$ KK-OwiG-Bohnert, Einleitung, Rdnr.1 ff.

${ }^{35}$ Se Greve, s. 61 f.

${ }^{36}$ I forbindelse med Ordnungswidrigkeiten er det ikke primær anklagemyndigheden, som står for forfølgningen, men den fagansvarlige forvaltningsmyndighed, $\S 35$ stk. 1 OWiG.

${ }^{37}$ KK-OwiG-Bohnert, Einleitung, Rdnr.143 ff.

${ }^{38}$ Roxin, s. 88 f.

${ }^{39}$ Betinget fængsel i op til et år kan kun pålægges, hvis den sigtede er repræsenteret af en forsvarer. Muligheden for at pålægge betinget fængsel blev i 1993 indført og er genstand for alvorlig kritik i Tyskland.

${ }^{40}$ Se Kausch, s. 66 ff.

${ }^{41}$ Lovens afgrænsning er, at lovovertrædelsen ikke skal være forbundet med en forhøjet mindste- 
straf, $\S 153$ stk. 1 s. 2 StPO.

${ }^{42}$ Det bliver i tysk litteratur diskuteret, om anklagemyndighedens kompetence virkelig er en sanktionskompetence eller en kompetence, som ligner en sanktionskompetence. SK-StPO-Weßlau, $\S 152$ Rdnr.35, beskriver $\S 153$ a stk. 1-proceduren som en "ikke-dommer afgørelsesform (...), som ender med en strafferetlig reaktion uden skylderklæring" ("nichtrichterliches Erledigungsverfahren (...), das mit einer strafrechtlichen Reaktion ohne Schuldspruch endet"). I denne artikel anvendes alligevel udtrykket sanktionskompetence (også i forbindelse med afgørelsesmulighederne af den danske anklagemyndighed), fordi forskellen først og fremmest synes at ligge i den dogmatiske klassificering af reaktionsformerne, end $i$ hvordan de i praksis opfattes af sigtede personer.

${ }^{43}$ Se LR-StPO-Rieß, § 153a Rdnr. 2 og 10. Der bliver imidlertid rejst spørgsmål i tysk litteratur, om der virkelig er tale om et konsensus, se slutnote 46 .

${ }^{44}$ Kriminalitet 1999, s. 4

${ }^{45}$ Kausch, s. 70 ff. og $240 \mathrm{ff}$.

${ }^{46}$ Roxin, s. 88 f.

${ }^{47}$ Hamm, s. 2982.

${ }^{48}$ Toftegaard Nielsen, s. 21.

${ }^{49}$ Gammeltoft-Hansen, s. 150 ff. og Roxin, s. 49.

${ }^{50}$ Roxin, s. $50 \mathrm{f}$.

${ }^{51}$ Fionda, s. 134.

${ }_{52}$ Aulinger, s. $112 \mathrm{f}$.

${ }^{53}$ Aulinger, s. 111 ff. (s. 114 ff.).

${ }^{54}$ Smith, s. 106 og Gammeltoft-Hansen, s. 186.

${ }^{55}$ Lov nr.385 af 25.5.1992. For baggrunden af ændringen se Betænkning 1066/1986.

${ }^{56} \mathrm{Se}$ art.29 TEU.

${ }^{57}$ Om EMRKs og Menneskerettighedsdomstolens voksende betydning i dansk straffeproces se Toftegaard Nielsen, s. $22 \mathrm{ff}$.

Adresse: Syddansk Universitet

IRFE

Campusvej 55

DK - 5230 Odense M

bfe@sam.sdu.dk 